\title{
AN EVALUATION ON INFLATION IN TURKEY AFTER 1980 AND THE ANALYSIS OF RELATIONSHIP BETWEEN INFLATION, INTEREST RATES AND EXCHANGE RATES
}

\author{
DOI: 10.17261/Pressacademia.2019.1111 \\ JEFA- V.6-ISS.3-2019(2)-p.124-134 \\ Begum Erdil Sahin ${ }^{1}$, Deniz Dilara Dereli² \\ ${ }^{1}$ Istanbul Kultur University, Department of Economics, Istanbul, Turkey. \\ b.sahin@iku.edu.tr, ORCID: 0000-0003-0452-1308 \\ 2 Istanbul Kultur University, Department of Economics, Istanbul, Turkey. \\ d.dereli@iku.edu.tr, ORCID: 0000-0002-9697-4571
}

Date Received: June 20, 2019

Date Accepted: August 21, 2019

To cite this document

Erdil Sahin, B., Dereli, D.D. (2019). An evaluation on inflation in Turkey after 1980 and the analysis of relationship between inflation, interest rateS and exchange rateS. Journal of Economics, Finance and Accounting (JEFA), V.6(3), p.124-134

Permemant link to this document: http://doi.org/10.17261/Pressacademia.2019.1111

Copyright: Published by PressAcademia and limited licenced re-use rights only.

\begin{abstract}
Purpose - Interest and exchange rates were determined by market dynamics after adaption of export-oriented industrialization model and liberalization of capital movements in Turkey after 1980s. Important steps have been taken by the Central Bank of Turkey to improve the effectiveness of monetary policy and the execution of monetary and exchange rate policies compatible with free market conditions. However, Turkey experienced chronically high inflation due to the crisis and political imbalances. In this study, the causality relationship between inflation, interest rate and exchange rate is evaluated.

Methodology - The relationship between inflation, interest rates and exchange rate are investigated by VAR Method for 2003: 01-2015: 02. The causality relationship between the variables are investigated by Granger causality analysis. Then, by impulse response analysis the responses of the variables to one-unit shocks and by variance decomposition analysis the explanatory of the variables on each other are investigated.

Findings- After 2008 global crisis, by 2010, the Central Bank adopted financial stability as well as price stability in monetary policy implementations. It is necessary to re-analyze the relationship between inflation, exchange rate and interest rate due to the changes in implementations against inflation during this period. The causality relationship between variables are examined by Granger ca usality test. As a result, a causality relationship from the interest rate to inflation is determined.

Conclusion- In this study the relationship between inflation, interest rate and exchange rate is examined in Turkey for 2005-2016 period. Findings of analysis result that interest rate is an effective variable on inflation and inflation rate is mostly affected by fluctuations in interest rates. Interest rates can be used as a policy tool against inflation which was the case for Turkey in the near past.
\end{abstract}

Keywords: Inflation, interest rates, exchange rates, VAR analysis.

JEL Codes: E40, E50, E31

\section{INTRODUCTION}

Inflation is one of the most important problems especially in developing countries. Inflation, which stands for continuous increases in the general level of prices, reduces the domestic purchasing power of goods and services and has a detrimental effect on income distribution in the economy. Therefore, inflation increases economic instability and also negatively affects economic performance (Doğan and et al. 2016: 406).

Inflation, interest rates and exchange rates act as pricing mechanism of a country and have impact on that country's macroeconomic conditions. A negative trend in any of these three variables leads to instability in a country's economy. Therefore, it is necessary to analyze the relation between them in order to identify and solve the root of the problem and to make appropriate adjustments in the applied economic policies (İşcan and Kaygısız, 2019: 583). The collaboration of financial markets with the goods market and the services market is essential for economic growth. In this context, the national income generated as a result of production is transferred to the goods market through consumption and savings. The realization of such transition without significant deviations ensures sustainability of production. In order to maintain a steady economic 
growth, the fluctuations in general price levels, exchange rates and interest rates should occur in a manner balancing each other (Özel, 2000: 7).

The economic structure is adversely affected because the deterioration of such parameters influences the balance of other domestic and foreign factors vis-à-vis each other as well as the alternative costs. However, the increases in exchange rates, inflation and interest do not indicate an absolute economic crisis, but unexpected fluctuations in these variables have a negative impact on distribution of social income and welfare (Sever and Mızrak, 2007: 266-267). A decrease in exchange rates leads to an increase in imports and a decrease in exports. As a result, the current account deficit increases. A decline in the exchange rates causes a decline in the price of imported intermediate goods, thus may lead to a decline in prices at general level. On the other hand, an increase in the exchange rates increases the prices of imported products and leads to inflation (İşcan and Kaygısız, 2019: 583-584).

The relation between inflation, exchange rates and interest rates is depicted in Figure 1. All three variables are affected by the conditions or changes in different industries. These three variables also interact with each other. Economic fluctuations could be either due to changes in exchange rates or inflation rates (Sever and Mızrak, 2007: 267). As the increases in exchange rates raise the prices of products produced through imported input, this causes a rise in the domestic prices of products. These increases are known to lead to high inflation and abandonment of domestic currency, especially in countries with high inflation rates. In addition, demand for foreign currency may lead to a further increase in exchange rates. Especially in countries where inflation is consistently high, savings are kept in foreign currency due to distrust to domestic currency. This circumstance increases the effect of exchange rates on prices and makes the economy quite unstable against changes in exchange rates (Figure 1)

\section{Figure 1: Relation Between Inflation, Interest Rates and Exchange Rates}

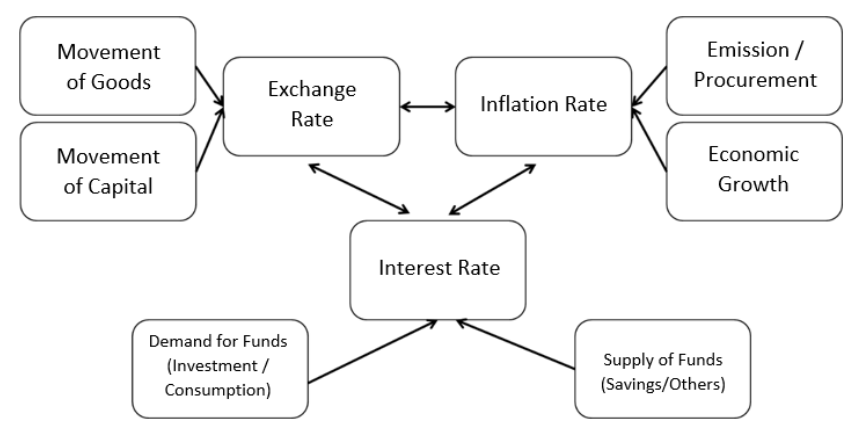

Source: Sever, E. and Mizrak, Z. (2007:267).

Fluctuations in supply-demand balance of foreign exchange can lead to inflation and devaluation (Central Bank of the Republic of Turkey, 2002). The global economic changes' impact on a country's economy depends on that country's macro-economic performance. Countries use interest rates to minimize negative consequences of such impacts. Changes in interest rates may lead to various changes in exchange rates based on country's exchange rate regime (İşcan and KaygıSIz, 2019: 584). The Central Bank influences inflation through various channels. The interest rates are often used as a basic tool for ensuring price stability. The monetary policies of countries are generated according to the inflation target within the scope of programs aiming to control inflation (Bernanke and Mishkin, 1997: 99). Future inflation targets are determined in order to reduce uncertainties and to create a positive expectation independent of previous or instantaneous rates. Interest is an important tool to achieve targeted inflation. In this context, operational autonomy and transparency of Central Banks are of significance. Besides the monetary policies adopted for the inflation target, fiscal and structural policies also have important implications for achieving that target (Carare and et al, 2002: 4-16).

Turkey started to deploy outward-oriented economic policies directed towards liberalization after 1980. Importation was liberalized within the framework of the economic stabilization program entered into force on January 24th, 1980, pursuant to which the Turkish Lira was devaluated; a flexible exchange rate regime was adopted; practices to encourage foreign capital and exportation were applied; price controls were ended; and a tight fiscal policy was initiated (Oktayer, 2010: 434). In connection with the export-based growth policy, the value of TRL was kept at low levels to encourage exports and eventually to increase export of goods and services (Yeldan, 2003: 48-49). Consequently, the inflation rate that was around $115.6 \%$ in 1980 lowered to $21.9 \%$, following which it started to increase again and raised to $73.7 \%$ in 1988 (Graph 1). 
Graph 1: Inflation in Turkey after 1980 (CPI \%)

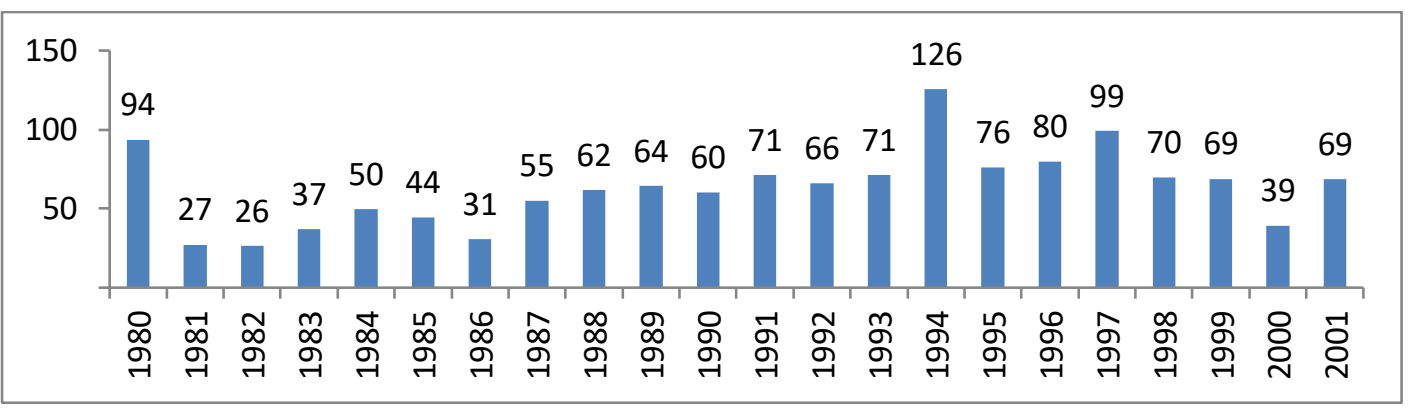

Source: Ministry of Finance; CPI: Consumer Price Index

In 1989, movement of capital was completely liberalized and there was a significant increase in foreign capital inflow to the country. The real exchange rate increased in value at a rate around $15-20 \%$ in the period between 1989 and 1990 . During the Gulf Crisis, the uncertainty in exchange rates mounted and the Central Bank focused on some practices in order to minimize this uncertainty (Berument, 2002: 4). However, financing policy applied after 1989 and based on high interest rates, exorbitant exchange rates, and the short-term capital inflow exposed the economy to a major crisis accompanied by uncertainty in exchange rates and financial markets in 1993. In 1994, the Turkish economy dived into that crisis with a high current account deficit and serious public deficits (Ülgen, 2005:84). The consumer price index, which was always below $20 \%$ until 1977 in the pre-1980 period, increased to $115 \%$ in 1980 and then up to $125 \%$ in 1994 when a crisis erupted (Kalaycl, 2002: 273). During this period, the Central Bank attempted to maintain stability in foreign exchange markets by using the foreign exchange reserves, and providing funds for the Treasury. Furthermore, the Economic Measures Implementation Plan was put into force in April 5th, 1994 in order to ensure economic stability. Within the scope of this plan, it was aimed to reduce the inflation rate, which had reached to $120 \%$, down to reasonable levels in the short term; and to redress the balance in financial markets and exchange rates; and to achieve sustainable growth through providing a permanent solution for public deficit and current account deficit in the medium term.

In 1995, instead of direct monetary policy instruments, indirect monetary policy instruments were introduced in line with modern central banking practices. Within the framework of the agreement signed with IMF, it was aimed to increase the foreign currency basket by predicted monthly inflation rates (Central Bank of the Republic of Turkey, 2013). As a result of such measures, some positive developments were achieved in 1994 and 1995. During this period, the ratio of exports against imports was improved thanks to devaluation; public deficit was decreased and short-term capital inflow followed a downward trend due to lower current expenditures (Yentürk, 2005: 67). However, a lasting success could not be achieved with the stabilization program introduced in 1994, and the country's economy went through a new shrinkage due to negative effects of the Asian and Russian crisis in 1998 (Yeldan, 2003: 159). A new crisis environment emerged with the effect of reasons such as shrinkage in domestic demand after 1998; decrease in Russia-based demand for our exports; and discontinuance of hot money inflow due to increasingly insecure environment and political uncertainties.

In 1999, a stand-by agreement was signed with IMF aiming to secure a solution. Additionally, with the "Inflation reduction program" covering a period of three years, the objective of fighting against inflation in the economy was brought into prominence (Oktayer, 2010: 435-436). This program was a continuation of the agreement signed with IMF, and covered the strategic targets and structural reforms identified for monetary and fiscal policy. The exchange rate was linked to a nominal anchor in the implementation of a monetary policy in line with the inflation reduction program (Kutlar and Gündoğan, 2012). The inflation reduction program based on the exchange rate anchor aimed to reduce the inflation rate by $25 \%$ by the end of $2000 ; 12 \%$ by the end of 2001 ; and $7 \%$ by the end of 2002 . Decreasing the real interest rates; increasing the capacity of economic growth; and ensuring a fairer allocation of resources were declared as primary objectives (Oktayer, 2010: 435-436).

The Inflation Reduction Program was implemented successfully until November 2000 in the Turkish economy. In this period, domestic demand exhibited an upward trend in the country; production volume increased; fiscal discipline was ensured in the field of public finance; and consequently the target of non-interest surplus was overachieved. However, despite such positive developments, the program did not reach its final targets of inflation. In 2000 , CPI decreased from $67 \%$ to $38 \%$ however still above the target. As a result, the exchange rate, which was adjusted to the inflation target, caused an excessive increase in the value of TRL and thus a decrease in exports (Oktayer, 2010: 436). Moreover, the increased interest rates as well as the increase in demand for imported goods due to overvalued TRY caused the current account deficit rise to 6.7 billion 
\$ in this period (Kutlar and Gündoğan, 2012). In addition to these imbalances encountered in the macro-economy, the negative developments in the banking sector impaired the trust to the financial sector, the government and the program and thus led the country's economy to the brink of two new crisis in November 2000 and February 2001 (Oktayer, 2010: 436).

After the crisis of 2001 outburst and loss of credibility, the exchange rate-based stabilization program was halted. The Central Bank left the exchange rates to fluctuate in February 22nd, 2001 (Central Bank of the Republic of Turkey, 2013). After this period, a new era begun in the Turkish economy and a new program called "Transition to a Strong Economy Program" was adopted in 2001. The main objectives of the new program were specified as preventing the instability occurred due to abandonment of fixed exchange rate system; and reducing the public debt within the scope of establishing an infrastructure directed towards restructuring the public administration (Aydoğan, 2004: 103). Program intended the restructuring of the economy and controlling the inflation. The Central Bank switched the inflation targeting strategy inflation to implicit inflation targeting as of 2002 and subsequently to open inflation targeting practice (Kalaycl, 2002: 273).

During this period, inflation was below targets respectively as 5.3\% in 2002; 1.6\% in 2003; and 2.7\% in 2004 (Yükseler, 2005: 33). At the end of 2005 , which was defined as a preparation period for transition to open inflation targeting, it was reduced to a reasonable level of $7.7 \%$. The economic growth was also recorded as an average of $7 \%$. At the end of 2005 , the Central Bank switched to open inflation targeting regime. Global economic developments had a negative impact on Turkey in the period after 2006. Especially, the change of international capital conditions to the disadvantage of developing countries caused capital outflows from Turkey. If the period between 2006, when the open inflation targeting was adapted, and 2018 is analyzed, it can be seen that the targets have not been achieved, except for the years 2009 and 2010. Especially in 2018, the significant increase in the inflation rate is noteworthy.

Graph 2 shows the targeted and actual inflation rates since 2006. The targets of the first 3 years, in which the open inflation targeting was implemented, were exceeded. Global fluctuations and the increase in global inflation rates incurred following the transition to open inflation targeting is the primary cause (Takım, 2011: 31). At the end of this period, the Central Bank went through a revision in the targeted figures for the first time. The targets fixed to $4 \%$ were later announced as $7.5 \%$ for 2009; 6.5\% for 2010; and 5.5\% for 2011 (Kutlar and Gündoğan, 2012).

The global economic crisis in 2008 caused an economic shrinkage. Accordingly, the increase in the energy and commodity prices and the imposed additional taxes caused pressure on inflation. In 2009, especially with the increasing effects of crisis, the inflation was realized as $6.53 \%$, a figure below the specified target arising from the decrease in the energy prices and levels of general demand. The production started to rise when the effects of crisis started to decline in 2010. The inflation rates mounted up to $10 \%$ in the first months of the year, but resulted as $6.4 \%$ by the end of the year due to the Central Bank's intervention in liquidity (Central Bank of the Republic of Turkey, 2013).

\section{Graph 2: Targeted and Actual Inflation Rates between 2006 - 2018 in Turkey}

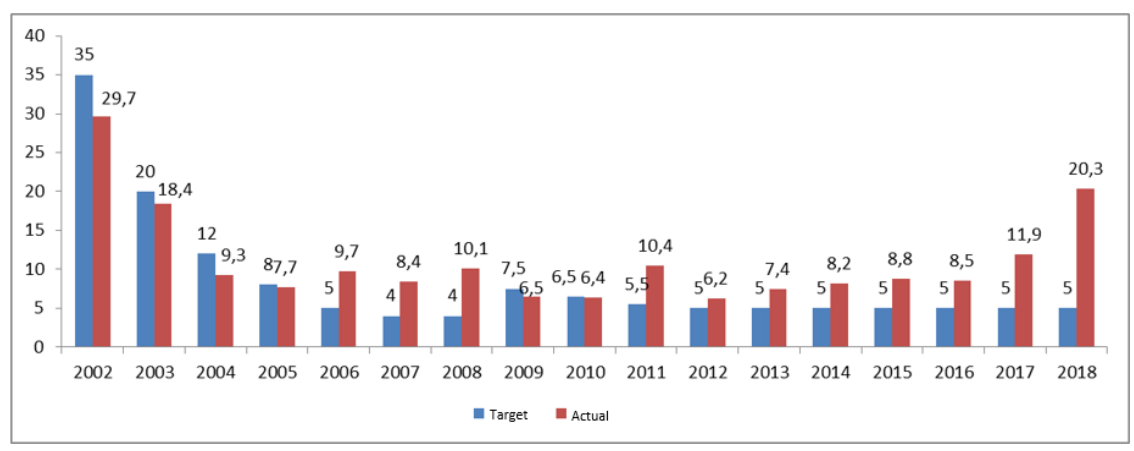

Source: Central Bank of Republic of Turkey

After the crisis, the Central Bank has started to employ new tools in order to keep inflation under control. The new approach was defined as implementation of an interest rate corridor. Central Bank aimed price and financial stability through loans and exchange rate transfer and by using monetary policy instruments such as interest rate corridor, weekly repo rates, liquidity management, and reserve requirements and reserve option mechanism (Central Bank of the Republic of Turkey, 2013).

In 2011, inflation reached to a level of $10.45 \%$, well above the targeted level of $5.5 \%$. The deviations in forecasts were mainly due to increase in unprocessed food prices over the estimations and the ongoing devaluation in Turkish Lira. The inflation rate was realized as $6.2 \%$, the closest level to the $5 \%$ target. This decline was mainly due to the abundance in food items and 
the decline in unprocessed food prices. With the effect of domestic and foreign political fluctuations, socio-political and global economic factors encountered after this period, the inflation reached up to $11.9 \%$ in 2017 and to $20.3 \%$ in 2018 , which is the highest level of the last 15 years (Fenira, 2014).

In this study, the relation between inflation, interest rates and exchange rates are described and development process of inflation in Turkey after 1980 is assessed. Also, the transition to the inflation-targeting regime in Turkey and describe the studies conducted in this context will be detailed in the literature section. In the final section, there will be an empirical analysis aiming to test the relation between inflation, interest rates and exchange rates.

\section{LITERATURE REVIEW}

Many studies were carried out examining the relationships between exchange rate, inflation and interest rate in Turkey for different periods. Some main studies carried out for Turkey and their findings are as follows:

İşcan and Durgun KaygıSIz (2019) analyzed the relationship between exchange rate, inflation and interest rate by using VAR model. Augmented Dickey-Fuller unit root test, Granger causality test, impulse response analysis and variance decomposition analysis are performed for Turkish economy in between 2009:01-2017:12 period. According to Granger test results causality relationship is found from exchange rate to both inflation and interest rate and also a causality relationship from inflation to interest rate are determined. While interest rate react negative to one unit exchange rate shock for 12 period, interest rate also gives negative reaction starting from the sixth period. Interest rate reacts positive for 2 terms to one-unit inflation shock. The most important factor on inflation and interest rate is found as exchange rate.

Dereli (2018) investigated the relationship between exchange rate and inflation in Turkey for 2005- 2017 period by VAR technique. A bi-directional causality relationship and a long-term relationship between inflation and exchange is found. According to study results exchange rate pass-through is high in Turkey.

Işıl and Özdemir (2018) investigated the relationship between inflation, interest rate and exchange rate in Turkey for 20032016 by dividing the period to two different terms and found causality from exchange rate to inflation after 2008.

Öner (2018) examined the relationships between nominal exchange rates, CPI and PPI inflation rates in Turkey for 2007:12017:12 period and performed Augmented Dickey-Fuller unit root test and Granger causality test. As a result, a one-way causality relationship from PPI to CPI is found, and it is determined that nominal exchange rate and the PPI are not affected by other independent variables.

By using VAR method, Bozdağlıoğlu and Yılmaz (2017) examined Turkish economy for 1994-2014 period and reached a oneway causality relationship from nominal interest rate to inflation.

Okur (2017) examined the effect of interest rate and exchange rate on inflation in Turkey for 2008:1-2016:4 period and found causality relationship between exchange rate, interest rate and inflation.

Bulut (2017) found one way causality from exchange rate to inflation in long term for Turkish economy between 2001: Q22017: Q3 period by conducting Cointegration test and Vector Error Connection Granger Causality test.

Doğan, Eroğlu and Değer (2016) investigated the causality relationship between interest rate and inflation by using data series of the inflation and interest rate in between 2003:01-2015:02. Augmented Dickey-Fuller and Phillips-Perron unit root tests, Granger causality test and Johansen Cointegration test are performed respectively. As a result of study, a single causality relationship is found from inflation to interest rate.

Torun and Karanfil (2016) investigated the relationship between inflation and interest rate for Turkish economy for 19802013 period. Model is established with inflation as dependent variable and interest rate, exchange rate and GDI as independent variables. Johansen cointegration, Granger causality and variance decomposition methodology applied. A longterm relationship is found between variables and unidirectional causality is found from interest rate and GDP to inflation. Additionally, bidirectional causality between interest rate and GDP has been found.

Atgür and Altay (2015) examined the relationship between the inflation and interest rate in Turkey for the period 2004-2013. The results obtained in the study have pointed to the existence of Fisher Effect in Turkey during the period 2004-2013. According to the Johansen, Lütkepohl-Saikkonen Cointegration Tests and Dynamic Least Squares (DOLS) method, a long-run relationship has been found between the inflation and nominal interest rates. 
Sever and Mızrak (2007) investigated the relationship between exchange rate and inflation in Turkey for 1987: 01-2006:06 period by VAR method. As a result of study, it is found that the changes in exchange rate effects both inflation and interest rate.

Güven and Uysal (2013) conducted Cointegration test and Granger causality test for Turkish economy for 1983-2012 period and found mutual causality relationship between exchange rate and inflation.

Güneş (2013) investigated the relationship between prices in Turkey, US Dollar and Euro with Cointegration analysis and Vector Error Correction Model (VECM) analysis. According to the study results, long-run relationship exist between prices in Turkey and the two exchange rates and the direction of relation is from both exchange rate to prices in Turkey.

Peker and Görmüş (2008) investigated the relationship between exchange rate and inflation by VAR method and found that changes in exchange rate is effective on prices in Turkish economy for 1987:1-2006:3 period.

Gül and Ekinci (2006), found a long term relationship between nominal exchange rate and inflation for 1984-2003 period in Turkey and also a causality relationship is reached from exchange rate to inflation

Işık, Acar and Işık (2004) examined Turkish economy for 1982:Q1-2003:Q4 and found long term relationship between inflation and exchange rate by conducting Johansen Cointegration test.

\section{DATA AND METHODOLOGY}

In this study, monthly data is used for the period between 2005-2016 in order to examine the relationship between exchange rate, inflation and interest rate. Series are seasonally adjusted. All variables are provided from Turkish Statistical Institution and are expressed in logarithmic form. Augmented Dickey-Fuller (ADF) test, VAR Granger Causality test, impulse response analysis and variance decomposition analysis are conducted. Serial Correlation LM test and White test, serial correlation and constant variance are checked. The analysis are carried out with Eviews 10.0. EXR, CPI and IR represent exchange rate, inflation and interest rate respectively.

\section{FINDINGS AND DISCUSSION}

By ADF test, stability of series are investigated and it is determined that variables are non-stationary at level form, but first differences of the series are stable. Calculated t-statistic values are bigger than McKinnon critical values which are 3.47, 2.88 and 2.54 at $\% 1, \% 5$ and $\% 10$ alpha levels respectively. The ADF test results are presented in Table 1.

Table 1: ADF Test Results

\begin{tabular}{|c|c|c|c|c|c|}
\hline \multicolumn{2}{|c|}{ Variable } & \multicolumn{2}{c|}{ Constant } & \multicolumn{2}{c|}{ Constant, Linear Trend } \\
\cline { 3 - 6 } & EXR & t-statistics & Probability & t-statistics & Probability \\
\hline \multirow{3}{*}{ Level } & CPI & -1.565 .628 & 0.4975 & -3780853 & 0.0204 \\
\cline { 2 - 6 } & IR & -1.476449 & 0.8986 & -3.408 .145 & 0.0543 \\
\hline \multirow{2}{*}{$\begin{array}{c}\text { First } \\
\text { Difference }\end{array}$} & DEXR & -9.127 .137 & 0.5458 & -1.840 .500 & 0.6798 \\
\cline { 2 - 6 } & DCPI & -1.044 .353 & 0.0000 & -9.172 .918 & 0.0000 \\
\cline { 2 - 6 } & DIR & -9.394 .289 & 0.0000 & -1.041 .492 & 0.0000 \\
\hline
\end{tabular}

Figure 2 shows that all of the characteristic roots of the model are contained within the unit circle that confirms the stability of the VAR model. In addition, it is necessary to determine the appropriate lag length to establish VAR Model for the causality test, impulse response analysis and variance decomposition analysis. The appropriate lag length for VAR model is selected as 2 at final predicting error (FPE), Akaike (AIC), Schwarz (SC) and Hannan-Quinn (HQ) values. 
Figure 2: Characteristic Roots

Inverse Roots of AR Characteristic Polynomial

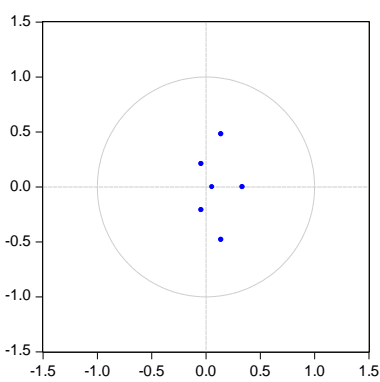

Prior to the VAR analysis, Granger causality test is performed and the causality relationship between variables is checked. As a result, a causality relationship from the interest rate to inflation is determined (Table 2).

Table 2: VAR Granger Causality/Block Exogeneity Wald Tests Results

\begin{tabular}{|c|c|c|}
\hline \multicolumn{3}{|c|}{ Dependent Variable: DEXR } \\
\hline Independent Variable & Chi-sq & Probability \\
\hline DCPI & 4.035342 & 0.1330 \\
\hline DIR & 0.569828 & 0.7521 \\
\hline \multicolumn{3}{|c|}{ Dependent Variable: DCPI } \\
\hline Independent Variable & Chi-sq & Probability \\
\hline DEXR & 2.186273 & 0.3352 \\
\hline DIR & 7.081155 & 0.0290 \\
\hline \multicolumn{3}{|c|}{ Dependent Variable: DIR } \\
\hline Independent Variable & Chi-sq & Probability \\
\hline DEXR & 3.250070 & 0.1969 \\
\hline DCPI & 0.808886 & 0.6673 \\
\hline
\end{tabular}

Autocorrelation between series and existence of constant variance are investigated by LM test and White test. Since probability value of White test is $>0.05$, no constant variance has been found. In addition, there is no autocorrelation between series. White test and Serial Correlation LM test results are presented at Table 3 and Table 4.

Table 3: White Test Results

\begin{tabular}{|c|c|}
\hline Chi-sq & Prob. \\
\hline 80.70329 & 0.2257 \\
\hline
\end{tabular}

\section{Table 4: Serial Correlation LM Test Results}

\begin{tabular}{|c|c|c|}
\hline Lag & LM Statistics & Probability \\
\hline 1 & 0.580285 & 0.8132 \\
\hline 2 & 0.656642 & 0.7479 \\
\hline 3 & 0.439301 & 0.9132 \\
\hline 4 & 1.568145 & 0.1238 \\
\hline 5 & 1.370628 & 0.2005 \\
\hline 6 & 0.996909 & 0.4424 \\
\hline 7 & 0.234132 & 0.9894 \\
\hline 8 & 0.166395 & 0.9971 \\
\hline 9 & 1.096399 & 0.3650 \\
\hline 10 & 1.061135 & 0.3914 \\
\hline
\end{tabular}


The effect of one-unit standard error shock at exchange rate on inflation is negative in the first period, followed by a positive course after the third period. When the effect on interest rate is evaluated, it is seen that there is a negative effect until the fifth period and the effect decreases after this period. The exchange rate reaction to one unit change in inflation is positive and decreases with a negative course after the fourth period. The reaction of interest is positive and decreases gradually after the fourth period. The exchange rate reacts positively to the one-unit standard error shock at interest rate, inflation reacts positive at second period, negative at third period and continues with a decrease over time.

\section{Graph 3: Impulse-Response Results}

Response to Cholesky One S.D. (d.f. adjusted) Innovations \pm 2 S.E.

Response of EXR to EXR

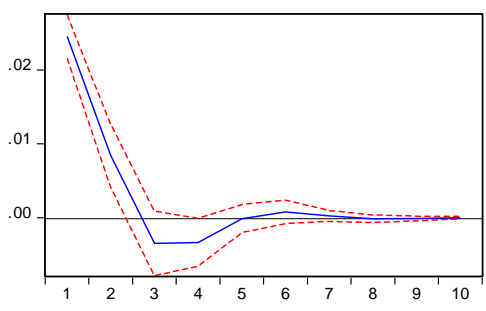

Response of $\mathrm{CPI}$ to EXR

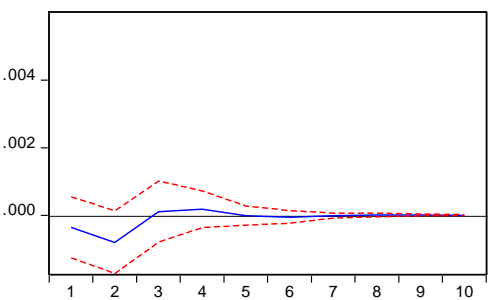

Response of IR to EXR

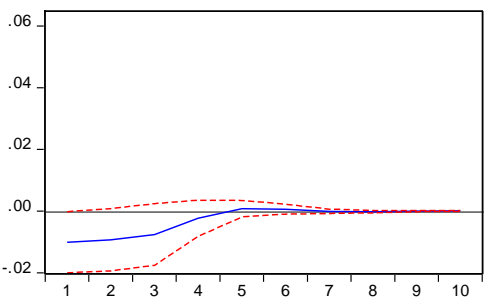

Response of EXR to CPI

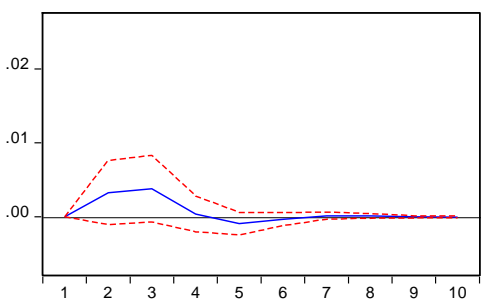

Response of $\mathrm{CPI}$ to $\mathrm{CPI}$

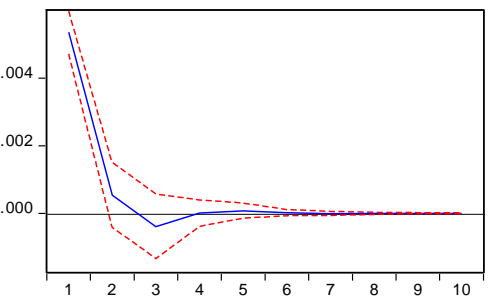

Response of IR to CPI

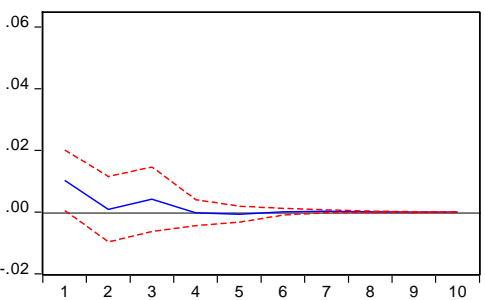

Response of EXR to $\mathbb{R}$

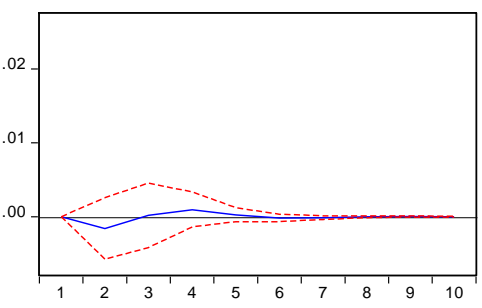

Response of $\mathrm{CPI}$ to $\mathrm{IR}$

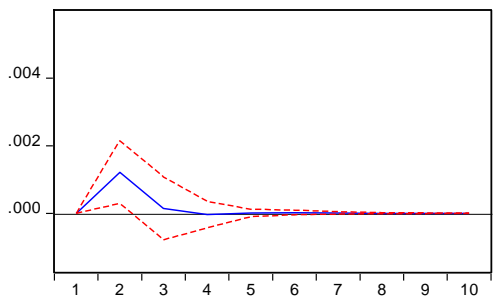

Response of $\mathbb{R}$ to $\mathbb{I R}$

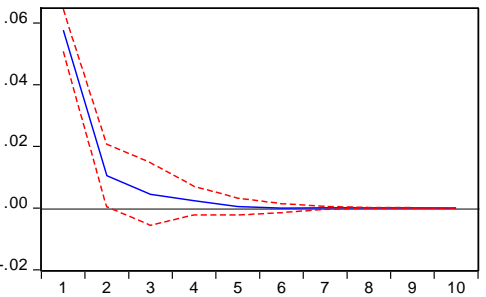

According to the results of variance decomposition analysis, changes in exchange rate is mainly explained by itself. In the following periods, it is seen that the inflation rate explains the changes in exchange rate by $3 \%$. The disclosure level of interest rate on the exchange rate is weak. On the other hand, inflation has a high level of self disclosure, while inflation explains the changes in interest rate by approximately $4 \%$ and the changes in exchange rate by $2.5 \%$. The real exchange rate is effective in explaining the changes in interest rates, and it is seen that this ratio has increased gradually after the first period and real exchange rate explains $\% 6$ of the changes in interest rate on average (Table 5).

Table 5: Variance Decomposition Results

\begin{tabular}{|c|c|c|c|c|}
\hline EXR Term & Standard Error & EXR & CPI & IR \\
\hline 1 & 0.024548 & 100.0000 & 0.000000 & 0.000000 \\
\hline 2 & 0.026210 & 98.08517 & 1.552798 & 0.362032 \\
\hline 3 & 0.026709 & 96.14299 & 3.502383 & 0.354623 \\
\hline
\end{tabular}




\begin{tabular}{|c|c|c|c|c|}
\hline 4 & 0.026934 & 96.05456 & 3.463160 & 0.482279 \\
\hline 5 & 0.026952 & 95.93200 & 3.575988 & 0.492015 \\
\hline 6 & 0.026966 & 95.91746 & 3.587580 & 0.494964 \\
\hline 7 & 0.026967 & 95.91361 & 3.590034 & 0.496356 \\
\hline 8 & 0.026968 & 95.91164 & 3.591996 & 0.496361 \\
\hline 9 & 0.026968 & 95.91157 & 3.591944 & 0.496482 \\
\hline 10 & 0.026968 & 95.91144 & 3.592075 & 0.496485 \\
\hline CPI Term & Standard Error & EXR & CPI & IR \\
\hline 1 & 0.005366 & 0.451405 & 99.54859 & 0.000000 \\
\hline 2 & 0.005587 & 2.497140 & 92.77026 & 4.732597 \\
\hline 3 & 0.005604 & 2.517329 & 92.71007 & 4.772605 \\
\hline 4 & 0.005606 & 2.613238 & 92.61341 & 4.773356 \\
\hline 5 & 0.005607 & 2.613349 & 92.61408 & 4.772574 \\
\hline 6 & 0.005607 & 2.621929 & 92.60502 & 4.773046 \\
\hline 7 & 0.005607 & 2.622419 & 92.60441 & 4.773169 \\
\hline 8 & 0.005607 & 2.622657 & 92.60419 & 4.773151 \\
\hline 9 & 0.005607 & 2.622746 & 92.60410 & 4.773155 \\
\hline 10 & 0.005607 & 2.622748 & 92.60410 & 4.773154 \\
\hline IR Term & Standard Error & EXR & CPI & IR \\
\hline 1 & 0.059429 & 2.908078 & 2.986701 & 94.10522 \\
\hline 2 & 0.061079 & 5.093496 & 2.848619 & 92.05788 \\
\hline 3 & 0.061856 & 6.481249 & 3.225549 & 90.29320 \\
\hline 4 & 0.061947 & 6.607295 & 3.217001 & 90.17570 \\
\hline 5 & 0.061957 & 6.618893 & 3.230505 & 90.15060 \\
\hline 6 & 0.061960 & 6.627494 & 3.230401 & 90.14210 \\
\hline 7 & 0.061961 & 6.627611 & 3.232011 & 90.14038 \\
\hline 8 & 0.061961 & 6.628578 & 3.232064 & 90.13936 \\
\hline 9 & 0.061961 & 6.628612 & 3.232104 & 90.13928 \\
\hline 10 & 0.061961 & 6.628644 & 3.232117 & 90.13924 \\
\hline
\end{tabular}

\section{CONCLUSION}

The relationship between inflation, exchange rate and interest rate is extremely important for developing countries. Especially prices are heavily affected by the changes in exchange rate. The changes in exchange rate effects both the costs and the prices of consumption goods as production in Turkey is dependent on imports. In high inflation periods, it is also difficult to control price changes. Investors demand high returns against risks and real interest rates increase. The rises in interest rate cause both cost inflation and demand inflation accordingly. The harmony between inflation, exchange rate and interest rate and low levels in these indicators are important for growth and realization of economic balances.

In Turkey, a significant shift in monetary policy has been realized by 2000s. In this context, the Central Bank, which aims to achieve price stability, has switched to explicit inflation targeting since 2002, and an open inflation targeting regime since 2006 and lowered the inflation expectations after 2008 global crisis, by 2010, the Central Bank adopted financial stability as well as price stability in monetary policy implementations. It is necessary to re-analyze the relationship between inflation, exchange rate and interest rate due to the changes in implementations against inflation during this period.

In this study the relationship between inflation, interest rate and exchange rate is examined in Turkey for 2005-2016 period. Augmented Dickey-Fuller unit root test, Granger causality test, impulse response analysis and variance decomposition analysis are performed. ADF test resulted that series do not contain unit root after first difference. The causality relationship between variables are examined by Granger causality test. The reactions of variables to the changes at other variable are analyzed by impulse response analysis. The disclosure levels of variables on each other are evaluated by variance decomposition test. As a result, it is seen that interest rate is an effective variable on inflation and inflation rate is mostly affected by fluctuations in interest rates. In this context, the result shows that interest rates can be used as a policy tool against inflation. As a matter of fact, the Central Bank used interest rate as a policy tool in the post-2002 period for price 
stability and a decline was observed in inflation rates. The determined explanatory nature of inflation on exchange rates reveals that exchange rates can be used effectively as a policy tool against inflation.

\section{REFERENCES}

Atgür, M. and Altay, N.O. (2015). Enflasyon ve Nominal Faiz Oranı Illişkisi:Türkiye Örneği (2004-2013). Celal Bayar Üniversitesi IiBF Yönetim ve Ekonomi Dergisi, 22(2), 521-533.

Aydoğan, E. (2004). 1980'den Günümüze Türkiye'de Enflasyon Serüveni. Yönetim ve Ekonomi Dergisi, 11(1), 91-110.

Bernanke, S. B. and Mishkin, F. S. (1997). Inflation Targeting: A New Framework for Monetary Policy. Journal of Economic Perspectives, 11 (2), 97-116.

Berument, M. H. (2002). Döviz Kuru Hareketleri ve Enflasyon Dinamiği: Türkiye Örneği. Bilkent University Publications: Ankara.

Bozdağlıoğlu, E.Y. and Yılmaz,M. (2017). Türkiye'de Enflasyon ve Döviz Kuru İlişkisi: 1994-2014 Yılları Arasında İnceleme. MBEU Akademik izdüşüm, 2(3), 1-20.

Bulut, Ş. (2017). Fiyatlar Genel Düzeyi ile Döviz Kuru Arasındaki Eşbütünleşme ve Nedensellik ilişkisi: Türkiye Örneği. Aydın iktisat Fakültesi Dergisi, 2(1), 1-10.

Carare, A. Schaechter, A. Stone, M. and Zelmer, M. (2002). Establishing Initial Conditions in Support of Inflation Targeting. IMF Working Paper, $02 / 102$.

Central Bank of the Republic of Turkey. (2002). Para Politikası Raporu, Temmuz-2002.

Central Bank of the Republic of Turkey. (2013). Enflasyon ve Fiyat Istikrarı. Central Bank of the Republic of Turkey Publications: Ankara.

Dereli, D.D. (2018). Türkiye'de Döviz Kuru ile Enflasyon Arasındaki Illişkinin Analizi (2005-2017). Turkish Studies, 13(30), 137-150.

Doğan, B. Eroğlu, Ö. and Değer, O. (2016). Enflasyon ve Faiz Oranı Arasındaki Nedensellik iliş̧kisi: Türkiye Örneği. Çankırı Karatekin Üniversitesi iktisadi ve Idari Bilimler Fakültesi Dergisi, 6(1), 405-425.

Fenira, M. (2014). Democracy: A Determinant Factor in Reducing Inflation. International Journal of Economics and Financial Issues, 4(2), 363375.

Gül, E. and Ekinci, A. (2006). Türkiye'de Enflasyon ve Döviz Kuru Arasındaki Nedensellik illişkisi: 1984-2003. Anadolu Üniversitesi Sosyal Bilimler Dergisi, 91-106.

Güneş, Ş. (2013). Türkiye'de Kur Rejimi Uygulaması ve Enflasyon İlişkisi Üzerine Bir Analiz. Ekonomik ve Sosyal Araştırmalar Dergisi, 9(2), 6577.

Işıl, A. and Özdemir, S. (2018), Enflasyon- Faiz Oranı ve Enflasyon-Döviz Kuru İkilemi: GEG Programı Döneminde Türkiye Gerçeği. Ege Akademik Bakış, 18(1), 153-165

Işık, N., Acar, M. and Işık, B. (2004). Enflasyon ve Döviz Kuru Illişkisi: Bir Eşbütünleşme Analizi. Süleyman Demirel Üniversitesi Iktisadi ve Idari Bilimler Fakültesi Dergisi, 9(2), 325-340.

İşcan, H. and Kaygısız, A.D. (2019). Türkiye'de Döviz Kuru, Enflasyon ve Faiz Oranı iliş̧kisi: 2009-2017 Uygulaması. Iğdır Üniversitesi Sosyal Bilimler Dergisi, 17, 581-604.

Kalaycı, Ş. (2002). Parasal Hedefleme, Enflasyon Hedeflemesi ve Enflasyonist Bekleyişler: Türkiye Ekseninde Bir Değerlendirme. Süleyman Demirel Üniversitesi Iktisadi Idari Bilimler Fakültesi Dergisi, 7(2), 271-284.

Kutlar, A. and Gündoğan, H. (2012). Türkiye'de 2008 Finansal Kriz Sürecinde Para Politikası ve Enflasyon Hedeflemesi. Türkiye Ekonomi Kurumu-Uluslararası Ekonomi Konferansı, 1-3 Kasım 2012, İzmir.

Oktayer, A. (2010). Türkiye'de Bütçe Açığı, Para Arzı ve Enflasyon İlişkisi. Maliye Dergisi, 158, 431-447.

Okur, A. (2017). Türkiye Ekonomisinde Faiz Oranı ve Döviz Kurunun Enflasyon Hedefi Üzerine Etkisi. Yalova Sosyal Bilimler Dergisi, 7(13), 146164.

Öner, H. (2018). Döviz Kuru ve Enflasyon Arasındaki Nedensellik Ilişkisi: Türkiye Uygulaması. Hitit Üniversitesi Sosyal Bilimler Enstitüsü Dergisi, 11(1), 343-358

Özel, S. (2000). Türkiye’de Enflasyon, Devalüasyon ve Faiz. Alkım Yayıncılık, İstanbul.

Torun, M. and Karanfil, M. (2016). 1980-2013 Dönemi Türkiye Ekonomisinde Enflasyon ve Faiz Oranı Arasındaki Illişki. Yönetim Bilimleri Dergisi, $14(27), 473-490$ 
Peker, O. and Görmüş, Ş. (2008). Türkiye'de Döviz Kurunun Enflasyonist Etkileri. Süleyman Demirel Üniversitesi iktisadi ve Idari Bilimler Fakültesi Dergisi,13(2), 187-202.

Sever, E. and Mızrak, Z. (2007). Döviz Kuru, Enflasyon ve Faiz Oranı Arasındaki İlişkiler: Türkiye Uygulaması. SÜ iiBF Sosyal ve Ekonomik Araştırmalar Dergisi, 7(13), 264-283.

Takım, A. (2011). Türkiye'de Para Politikası Stratejilerinin Fiyat İstikrarına Etkisi: Enflasyon Hedeflemesi Örneği. ZKÜ Sosyal Bilimler Dergisi, 7(13), 15-35.

Uysal, D. and Ayvaz Güven, E.T. (2013). Türkiye'de Döviz Kurlarındaki Değişme ile Enflasyon Arasındaki İlişki (1983-2012). Akademik Araştırmalar ve Çalışmalar Dergisi, 5(9), 141-156.

Ülgen, G. (2005). Türkiye'de Piyasa Ekonomisine Geçiş ve Sürdürülebilirliği. Derin Yayınları, İstanbul.

Yeldan, E. (2003). Küreselleşme Sürecinde Türkiye Ekonomisi. İletişim Yayınları, İstanbul.

Yükseler, Z. (2005). IMF Programları ve Enflasyon Hedeflemesi: Brezilya Deneyimi ve Türkiye İçin Dersleri, Türkiye Ekonomi Kurumu Tartışma Metni, 2005/9.

Yentürk, N. (2005). Körlerin Yürüyüşü: Türkiye Ekonomisi ve 1990 Sonrası Krizler. Bilgi Üniversitesi Yayınları, İstanbul. 